\title{
6
}

\section{Old wine in new bottles? The continued relevance of Cold War strategic concepts}

\author{
Robert Ayson
}

Cold War strategic concepts played a significant part in my time as a student at The Australian National University (ANU). Arriving in Canberra in the early part of 1988, the penultimate year of the multidecade struggle between East and West, I joined the smaller predecessor to today's much larger master's program. The core course in that original master's degree was dominated by a subject that has largely disappeared from today's teaching in strategic studies. This was the strategic nuclear balance between the United States and the Soviet Union and, in our case, there was a particular focus on the development of US nuclear strategy.

I owe a great deal to those half dozen nuclear strategy lectures and to the wonderful academic who delivered them: Professor Desmond Ball. In his classes, Professor Ball examined in detail the stability of that superpower nuclear balance. And it was the concept of stability in the Cold War period, and specifically Tom Schelling's work on that idea, that formed the topic of my PhD thesis at King's. Had it not been for the encouragement from Strategic \& Defence Studies Centre (SDSC) academics who had taught me here in Canberra, I expect I would have had little chance of working in London with Lawrence Freedman, whose enthusiasm for the history of strategic ideas continues to be a major inspiration to me. 
With that background, you might expect me to choose stability as my chosen strategic concept from the Cold War. That possibility did cross my mind. But instead I will look at something stemming from another topic we covered in that 1988 core course. In this case, however, there was but one lecture. The theme was crisis management, and our teacher that day was Coral Bell.

Crisis management among the great powers, often against the risk of nuclear annihilation if these crises were mismanaged, runs through a good deal of Bell's work. In reading her slim volume, The Conventions of Crisis, while I was on sabbatical here in 2013, one concept stood out to me as an approach to understanding the management of Great Power crises. This was an idea that Bell said she had borrowed from the Soviet specialist Marshall Shulman. ${ }^{1}$ It was to view the relationship between the main Cold War protagonists, the US and the Soviet Union, as an adverse partnership. And that concept is my focus in this chapter.

So what does, or perhaps what did, an adverse partnership consist of, and why was it important? As for the first question, an adverse partnership is pretty much what its two component words in combination suggest it to be. It is to regard adversaries, even when they are very serious rivals, as possible partners. It is to suggest that two or more great powers, whose relationship is characterised by deep competition, can nonetheless also find ways to work together, presumably on the basis that they have common interests as well as conflicting ones. A primary focus for their limited cooperation is the conscious management of the conflict that exists between them, avoiding its escalation into a situation that both of them will regret.

At the same time, we should not get too carried away, and Bell was generally not one to do so. An adverse partnership also implies that even when we do see great powers working together, we should not be fooled into thinking that they are no longer adversaries. These partners remain adversaries. Their limited cooperation is much more about coexistence than friendship. There is nothing harmonious here.

1 See Coral Bell, The Conventions of Crisis: A Study in Diplomatic Management, Oxford University Press for Royal Institute for International Affairs, London, 1971, p. 50n. 
By 'adverse partnership' [she explained], I do not mean to imply anything particularly cordial, trusting or friendly: only a consciousness, between the dominant powers, that they have solid common interests as well as sharp conflicting interests. ${ }^{2}$

The main point is that cooperation can coexist with competition. Neither one of these facts of international life needs to rule out the other.

And why is the idea of an adverse partnership important? Let me give two answers to that question. One applies to our own fading memories of the Cold War period, memories that we now seldom have in common with the majority of our students, who were born some years after the Berlin Wall was torn down. When I ask my undergraduate students for their first political memory, for some of them it is $9 / 11$. But some of them do not even remember that far back.

For their benefit, it concerns me when the Cold War is stereotyped because of academic laziness or because of the simplification of complex history to serve geopolitical agendas. Academically, I do not take much relief from any view, however widely accepted it may be, that the United States and China are not sliding into a US-Soviet-style Cold War. To establish that position is no reason to take our eyes away from the still hazardous strategic competition between Beijing and Washington. Geopolitically, we should be wary of arguments that drawing Cold War parallels is a no-go zone. For the United States, acknowledging the possibility of a Cold War with China may also be to endorse containment as a central Cold War strategy. For China, the lesson from Russia's experience is that a cold war can end with the dissolution of the contained power. Moreover, for great powers like China and Russia that remain outside the US alliance system, there is the convenient argument that these alliances reflect an obsolete Cold War mentality. Most of these positions say much more about political preferences than they do about accurate perceptions of the situation.

Amid these politically charged battles for the interpretation of the postwar order, it is not surprising if some of our students see the Cold War as a period of unrelenting zero-sum competition. But the idea that the principal adversaries of that era can be regarded as partners as well as competitors suggests that this view is false. This is one reason why thinking about adverse partnerships is important. To regard Soviet Russia and the United States as adverse partners is one way of reminding ourselves, and

2 Ibid., p. 50. 
our students, that Cold War tensions and anxieties waxed and waned. It helps us remember that, although these tensions were very serious and dangerous, they did not lead inevitably to war.

Above all, this picture of Great Power relations reminds us that in some situations rivals can actually manage their conflict. For those of us who like to emphasise the role of agency in strategy, and to suggest that strategic actors have choices that can affect the choices of others, the notion of an adverse partnership becomes even more significant.

Second, the conception of a US-Soviet adverse partnership is important for its place in debates that went on during the Cold War. We forget how revolutionary it was to argue that the two supposedly implacable foes could also be seen as partners. The United States and Soviet Union were after all geopolitical, ideological, economic, cultural, military, diplomatic and sporting rivals. The notion that they could also be partners rested uneasily alongside that fact.

This argument was perhaps not quite so hard for Coral Bell to make; after all, The Conventions of Crisis was published in 1971, by which time the short-lived superpower détente had well and truly taken hold. This was a year before the Strategic Arms Limitation Treaty I (SALT I) talks, including the Anti-Ballistic Missile (ABM) Treaty, would be completed successfully, a formal sign of the ability of the two superpowers to set limits on their nuclear competition. Washington and Moscow might have defined strategic stability in less than identical ways, but their arms control agreements reflected their joint assessment that they had a common interest in regulating a major aspect of their Cold War competition. ${ }^{3}$ Both saw mutual survival as a core interest, to use a term that has become associated with the foreign policy of today's China. But unlike Beijing's assertions today, it was a core interest the two sides had in common.

Today we are probably even more comfortable with the argument that the major nuclear powers needed to see themselves as partners in avoiding mutual annihilation. But in the late 1950s, when a fairly young American economist was asserting that the nuclear-armed superpowers had common interests (as well as competitive ones), he was actually explaining a point of departure for post-war strategic studies. This economist was Thomas Schelling, who argued that it was best to characterise the US-Soviet

3 I take this argument from Hedley Bull, The Control of the Arms Race: Disarmament and Arms Control in the Nuclear Age, Weidenfeld \& Nicolson, London, 1961, p. 10. See my analysis in Robert Ayson, Hedley Bull and the Accommodation of Power, Palgrave Macmillan, London, 2012. 
bilateral strategic interaction as a non-zero-sum bargaining relationship. They were not the pure competitors that orthodox microeconomics suggested would lead naturally to a market equilibrium. Instead, they were more like the two big oligopolistic firms whose every move depended on the move the other made, and whose self-interests did not include the disappearance of each other. ${ }^{4}$

The superpowers were like members of a cartel who needed to regulate their conflict out of mutual interest, where the market mechanism could not be relied on. They were, in other words, adverse partners (a term I do not think Schelling himself quite came to use). Lawrence Freedman identifies this logic perfectly when he argues, in his epic Evolution of Nuclear Strategy, that '[a]t the centre of the strategy of stable conflict was the concept of incomplete antagonism'. ${ }^{5}$ The follow-on from that statement is that the incomplete antagonism provided an opportunity for managing the conflict.

Strategy to Schelling was a question of manipulating risk, but this logic worked only if you thought the other side had an interest in keeping the competition within limits. Threats of harm were more important than actual violence, and they were also more meaningful because actual violence could be so utterly devastating in the nuclear age. ${ }^{6}$ Once the Russians had broken the United States' nuclear monopoly, a full-scale nuclear exchange would resemble the category of absolute war, which Clausewitz, writing more than a century beforehand, had suggested was philosophically necessary but which in normal circumstances was practically unreachable. Bernard Brodie's famous warning in 1946 that from now on armed forces must be used to prevent war rather than prosecute $i^{7}$ had indicated that nuclear weapons, if not managed properly, could make Clausewitz's philosophical category all too real. This was just how it seemed to Hedley Bull, a close follower of Schelling's work, who suggested that the nuclear age had also rendered obsolete Clausewitz's observation that war did not consist of a single instantaneous blow. ${ }^{8}$

4 See Thomas C. Schelling, The Strategy of Conflict, Harvard University Press, Cambridge, MA, 1960.

5 Lawrence Freedman, The Evolution of Nuclear Strategy, 2nd edn, Macmillan/St Martin's Press with International Institute for Strategic Studies, Basingstoke and New York, 1989, p. 208.

6 He developed this theme in Thomas C. Schelling, Arms and Influence, Yale University Press, New Haven, 1966.

7 Bernard Brodie, The Absolute Weapon, Harcourt Brace, New York, 1946, p. 74.

8 See Hedley Bull, 'Society and anarchy in international relations', in Diplomatic Investigations, ed. Herbert Butterfield and Martin Wight, Allen \& Unwin, London, 1966, p. 46. 
We know that Bull also favoured the logic of adverse partnerships even though he also probably did not use the term. This precocious scholar, who took up his ANU chair a year after the SDSC was established, argued that the great powers had a special responsibility to recognise and nourish their common interests in the working of an international society. Principle among those common interests was the avoidance of major war, which the presence of nuclear weapons would make especially catastrophic. Bull saw that a fairly crude equilibrium of power in the form of the balance of terror had been created by the superpower arms race. But he argued that there was nothing permanent about this situation, which he therefore referred to as an accident of history. Instead, the Americans and the Russians were obliged to take deliberate steps to manage their conflict if deterrence was to be stable. They needed to recognise, in other words, that they had to be partners in order to manage the most dangerous aspects of their adverse tendencies.

It would be wrong to suggest that this theme was recognised consistently by all who adopted it, or that each one of the scholars mentioned here saw the adverse partnership operating in the same fashion. In 1980, as the Cold War was reintensifying, Bull, now back in Oxford, launched a stinging attack on Moscow and Washington for ignoring their Great Power responsibilities to international society, including their retreat from arms control. ${ }^{9}$ But barely half a decade later, and a year after Bull's untimely death in 1985, John Lewis Gaddis described in his essay, 'The long peace', the rules of the game that both the United States and the Soviet Union had adhered to in order to maintain a measure of stability in their otherwise hazardous relationship. ${ }^{10}$ Bull might well have agreed with Gaddis here as he had a strong tendency to disagree with himself. But years earlier, when the superpowers were in the middle of relaxing their tensions, even Shulman was not sure they had got it right. In 1971 he argued:

security in the realm of strategic weapons would be best served by a stable equilibrium at as moderate a level as can be managed through explicit or tacit agreement with our adversaries. On this point, the interests of the two countries are not opposed, but on neither side is this fact yet fully appreciated. ${ }^{11}$

9 See Hedley Bull, 'The great irresponsibles? The United States, the Soviet Union and world order', International Journal 35, no. 3, 1980, pp. 437-47.

10 John Lewis Gaddis, 'The long peace: Elements of stability in the post-war international system', International Security 10, no. 4, 1986, pp. 99-142.

11 Marshall Shulman, 'What does security mean today?', Foreign Affairs 49, no. 4, 1971, p. 617. 
All of these perspectives could be right, of course. If partners are also adversaries, we cannot expect their partnership to be smooth or thoroughly consistent. Theirs is a rocky marriage in which they cannot live with each other but cannot live without each other as well. This helps us paint a more realistic view of Cold War strategic relations than the cardboard cut-out varieties we see in so much of the modern discourse. Just as some see the Cold War as an especially difficult and competitive period of international politics, which today's Asia cannot afford to repeat, some others are tempted to look back nostalgically on an era that was not nearly as simple or stable as they might think. It is easy to forget that some of the crises that were survived in the Cold War could have become very serious.

This makes it even more important to lay out the factors that made for an adverse partnership. I think there were five of these in the Cold War adverse partnership.

The first of these might seem striking for us today. For the most part, when we think about US-Soviet Cold War strategic relations, the first thing that does not come to mind is their economic relationship. Containment was possible, we might think, because they were members of separate economic systems: one open and liberal, the other closed and centralised. But things were more complex than this initial picture suggests. There was at least some economic exchange, including in wheat sales. In a 1973 essay, Shulman argues that a 'cooperative side of the economic relationship' was 'reflected in the massive Soviet effort to expand its imports of grain, technology and consumer goods, and to develop Western markets for Soviet goods to pay for these imports in the future'. ${ }^{12}$ But it would be an entirely different step for us to assert that the Russians and Americans could always fall back on their common economic interests when the going got tough. This is worth remembering if we think that all the great powers have to do in the 21 st century to run an adverse partnership is to attend to their relationships of economic interdependence.

The Cold War adverse partnership was based much more on restraint in the political-military arena, in the issues we in strategic studies tend to focus on.

12 Marshall Shulman, 'Toward a Western philosophy of coexistence', Foreign Affairs 52, no. 1, 1973, p. 38. 
But the nature of this restraint brings to mind a second important factor. To use Schelling's terminology, to which I am somewhat addicted, the adverse partnership was as much tacit and informal as it was explicit and formal. At times it was so tacit that the very existence of a partnership was plausibly deniable.

We should not overlook the importance of formal agreements such as the ABM Treaty, and other obvious collaboration including Incidents at Sea Arrangements. But, as Bull argued, these agreements were but symbols of the deeper recognition of common interests that constituted the limited understanding between East and West. A great deal still depended on the unilateral nature of that restraint. Tacit signalling, as opposed to formal negotiation, mattered a great deal. Bell asserts in The Conventions of Crisis that 'the basic instrument of crisis management is what I shall call the signal':

By signal I mean a threat or offer communicated to the other party or parties to the crisis. Such signals [she added] are not necessarily verbal messages. Some of the sharpest and most effective of them are movements of military resources of various sorts. ${ }^{13}$

But therein lies a potential problem. One wonders whether the adverse partnership was akin to what Hedley Bull once said about Schelling's tacit bargains. As he said in reviewing Schelling's Arms and Influence:

I find it hard to recognize American and Soviet behaviour in his picture of two governments orchestrating by purposive individuals, sending and receiving messages and ironing out understandings in these ... fields with scarcely as much as a nod or a wink. ${ }^{14}$

A third factor is that these threats of force and other signals were used to sustain the central agreement on which the partnership relied. This was the informal agreement to avoid actual major hostilities. There might also have been something of a tacit understanding to deflect the competition into other areas, including the fighting of proxy wars, the competition for allies and the arms race itself. ('In modern conditions', Bell tells us, 'it is only wars of limited objective and limited liability that have been found

13 Bell, The Conventions of Crisis, p. 73. A number of these themes had been explored by Schelling, including in T.C. Schelling, 'Signals and feedback in the arms dialogue', Bulletin of the Atomic Scientists 21 , no. 1,1965 , pp. 5-10.

14 Hedley Bull, 'Review of Arms and Influence by Thomas C. Schelling', Bulletin of the Atomic Scientists 23, no. 3, 1967, pp. 25-6. 
feasible. ${ }^{15}$ But even limited wars between the superpowers were out of bounds.) The crucial point is that so much of the conflict management that did occur did not happen through carefully calibrated exchanges of actual violence-it was conflict management through coercion and the management of that coercive diplomacy itself. If we regard mutual deterrence in the way Schelling refers to it as the exchange of all possible hostages, ${ }^{16}$ we can see how coercion (in the form of the threats of major harm) was used to sustain a joint no-attack commitment.

And a fourth stems from that: the incredibly high stakes of the game that was being played. I do not think even the most worrying climate change picture we can imagine today can quite compete with the potentially instantaneous gravity of a full-on thermonuclear exchange. The difference of course is that we are already getting at least some climate change. There is a good chance the world will never experience thermonuclear war; however, it was when both sides during the Cuban Crisis stared at the brink of that apocalypse that the arguments of Thomas Schelling, Hedley Bull and others really gained wings. It meant that the fostering of an adverse partnership was not desirable. It had become essential.

A fifth factor also has to be mentioned: how dependent others were on the adverse partnership that the two great nuclear powers were willing and able to strike. This feature only reinforced their dominance of the international system. The adverse partnership was an agreement between the elite powers, and it meant a willingness to subordinate the interests of even close allies if these got in the way. The two main powers remained in a more or less oligopolistic position, although in Asia, with China's emergence, more of a triangle emerged.

An obvious and necessary question to ask is whether this formulation does have continued relevance. Given my argument that we often exaggerate the competitiveness of Cold War relations in comparison to our perception of today's Great Power picture, and my corresponding view that there is more continuity than we are often led to believe between the Cold War and post-Cold War worlds, you might think my answer to this is a resoundingly positive one.

15 Bell, The Conventions of Crisis, p. 49.

16 Schelling, The Strategy of Conflict, p. 231. 
My answer is yes, but only to a point. Let me explain what I mean courtesy of the most obvious early 21 st-century test case for an adverse partnership, nothing other than today's Great Power interaction between the United States and China. How that relationship evolves, and what it means for Asia's security, and what that then means for Australia, will be the most important set of connected questions for many of the next 50 years of the SDSC. So this is no idle consideration.

In the second decade of this new century, we are not as surprised as some Cold War audiences might have been about the possibility of adverse partnerships. ${ }^{17}$ After all, we are all aware of the close economic relations that the United States and China enjoy, which give them a common economic interest the Russians and Americans largely lacked. Hence, the first consideration regarding the adverse partnership seems in much better nick today than in the era of East-West strategic interaction.

Yet I wonder whether there is a problem here. The economic interconnectedness between China and the United States is at least partly an accident of economic history. It is as much a consequence of a decision made by Deng Xiaoping and his successors for China to engage the global economy and of the activities of self-interested US commercial enterprises as it is a deliberately choreographed situation that has been cooked up between Beijing and Washington. This interdependence is not the guarantee of a commitment to conflict management that some might want to think.

In terms of the second factor, we had better hope that the conflict management that does occur directly between China and the United States lies through informal, tacit and unilateral actions. I say that because there is not a great deal of evidence for formal security collaboration.

This is not the end of the world. The two sides can work together without counting rules, without incidents at sea agreements and even without China's involvement in whatever will become of Strategic Arms Reduction Treaty (START). They do not necessarily require an Asian version of the Conventional Armed Forces Treaty. Nor do they need the East Asia Summit to do the impossible and create some real institutional legs. They can also agree to work together in formal responses to the security

17 For one significant depiction of their other than zero-sum relationship, see Rosemary Foot, 'China and the United States: Between cold and warm peace', Survival 51, no. 6, 2009-10, pp. 123-46. 
challenges that third parties pose to international and regional securitythink of joint US and Chinese involvement in the Iran nuclear deal, or their ability occasionally to vote for the same resolution on North Korea at the Security Council.

But in terms of their management of their own bilateral security relationship, the formal symbols of a deeper understanding are few and far between. This does not mean that they cannot have such an understanding. The two sides meet regularly at the US-China Economic and Strategic Dialogue. Washington and Beijing recognise that they have a common interest, for example, in not allowing their South China Sea grandstanding to escalate to war. They have a common interest in making sure that Taiwan continues to avoid moving formally to independence. They recognise a common interest in avoiding war in the East China Sea, and in ensuring through compatible unilateral signalling that Tokyo does not push either of them too far in that direction.

If there is such a common underlying commitment to keeping their own conflict within limits, that is well and good. But I am not sure how persuaded we should be of this. Does the relative absence of formal signs, including in arms control, suggest that the underlying informal understanding has not really been struck, or needs renegotiating? I wonder how much of an adverse partnership is really there.

At least initially, the third factor seems to be met without any question. This is a mutual commitment to use coercion rather than war itself as a way of managing the conflict, and indeed as a way of avoiding severe escalation to war. There has been no major power war in Asia for decades, and the commitment of the United States and China to avoid war in their own relationship needs mentioning here. Moreover, evidence of threats of force are not difficult to find. In the last few years, the United States, alongside its allies Japan and Australia, have accused China of using coercion to change the maritime status quo in East Asia, in both the South and East China Seas. Whatever the merits of these claims, it must be accepted that Washington cannot, and does not, accuse Beijing of using violent force, including actual hostilities, to achieve its foreign policy objectives. And few expect major war between the United States and China to be around the corner, even if some feel the tensions between them are growing. 
Similarly, an often overlooked fact is Washington's reliance on coercion to achieve its strategic objectives in Asia, including, if we are to believe the implied messaging, to protect the status quo. That coercion includes the United States' freedom of navigation patrols, its extended deterrence commitments to key regional allies and its strengthening of defence cooperation with South Korea to forestall a greater challenge from North Korea. This coercion also includes the United States' direct deterrence of China (and vice versa). There is all manner of signalling going on here.

This coercion on the part of China and the United States is not one of Hedley Bull's accidents of history. It is conscious activity designed to influence the expectations and behaviour of the other side, and to influence the expectations and behaviour of others in the region. There is enough evidence to suggest that China and the United States wish to avoid war in their relations and to keep any sabres rattling rather than brandished in an actual engagement. There is also enough evidence to suggest that they can work together to manage the interaction of their coercionthink of their cooperation after the EP-3 spy plane incident and the now fairly regular management of some fairly hairy moments on the high seas. But it is a bit less clear how well they are able to manage their coercive interactions in a properly heated bilateral crisis. An adverse partnership requires a measure of crisis stability that we might wonder about.

One of the reasons for these concerns is connected to the fourth factor: that the Cold War adverse partners had seen the abyss in the Cuban Crisis and were aware what was at stake should their conflict not be managed. That abyss was created by an intense competition for nuclear parity that we do not see in the more asymmetric US-China nuclear interaction. I do not want the United States and China to be more scared of one another than they need to be, but you have to wonder whether they are quite scared enough. Despite all of their economic interactions, I am just not sure how much Washington and Beijing both believe that they must see each other as partners as well as competitors in their security interactions in Asia today. And I wonder whether they see an adverse partnership as completely necessary. Are they more inclined to think that they can press on with their aims - which for the United States includes the maintenance of regional primacy and which for China includes challenging that status quo-without worrying quite as much as we would want them to about the risks of that behaviour? It is a concern of this sort that I think led 
Hugh White towards his China Choice. ${ }^{18}$ There, his sharing of power argument strikes me as more ambitious than Coral's adverse partnership, based as the latter is on a similar recognition that there are common as well as competitive interests between the two.

What about the rest of us in the Asia Pacific, or, as Australia now likes to say, the Indo-Pacific? There is no doubt that the fifth factor applies: that the wider region depends heavily on the ability of China and the United States to mix a bit of partnering with their competition. In Asia's Security, I was looking for those factors that linked the wider region together in security terms. I did this to allow us to talk about the security of Asia rather than just security somewhere in the region. My assessment, which should probably not surprise any of us, is that the China-US strategic interaction was the most important of these system-wide factors. ${ }^{19}$

This raises a further question. If the extent and quality of the China-US adverse partnership affects the rest of us, what does this mean in reverse? How much impact can we have through our own choices on the quality of their interaction? If an adverse partnership is in essence a way of managing conflict, what role do third parties have in helping that management? Is there more room today than there was in the Cold War for that to be happening? If the answer is yes, we had better get our strategic skates on.

\section{Conclusion}

My final point here is that the idea of an adverse partnership can do more than tell us a good deal about the US-Soviet strategic interaction during the Cold War. And it can do even more than offer us some good questions to ask about great power strategic relations today. I think the adverse partnership idea tells us a great deal about the nature of our subject. It can remind us what strategic studies is about. I say this because at the heart of the adverse partnership is the management of conflict. Schelling's book, still hugely influential, is The Strategy of Conflict. But while Strategy as Conflict Management might not sound fantastic as an alternative title, I think it could be closer to home.

18 See Hugh White, The China Choice: Why America Should Share Power, Black Inc., Melbourne, 2012.

19 See Robert Ayson, Asia’s Security, Palgrave Macmillan, London, 2015. 
Strategy is not only the management of war, which is a subset of conflict. It is not the mere study of conflict, because, as Brodie once said, 'strategy is a theory for action. ${ }^{\prime 20}$ It is not just the pursuit of ends through available means, because to manage conflict is to have a deliberate influence on other actors in our interactions with them. Strategy is therefore much more than the use of conflict and threats of conflict. It is the conscious regulation of conflict as a fact of international life, whether in wars hot or cold or somewhere in between. 
This text is taken from New Directions in Strategic Thinking 2.0:

ANU Strategic \& Defence Studies Centre's Golden Anniversary

Conference Proceedings, edited by Dr Russell W. Glenn, published 2018 by ANU Press, The Australian National University, Canberra, Australia. 